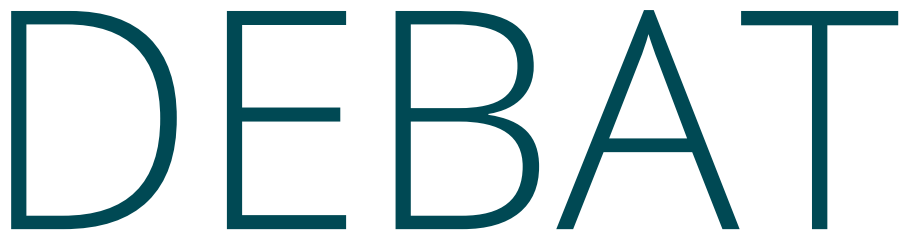

\title{
Så lige pludselig skulle vi sådan rigtig til at samarbejde
}

Et notat i 2017 skabte frygt for fremtiden. Men det kan være svært at se graden og omfanget af et samarbejde, før man kommer i gang.

Jeg kan stadig huske det morgenmøde på biblioteket i april måned 2017, hvor vi blev præsenteret for visionerne og de pludselig helt konkrete planer for, at vi skulle indgå en samarbejdsaftale med det stadig helt ny-fusionerede Kongelige Bibliotek. Eller, hvis jeg skal være helt ærlig, så er det ikke så konkrete minder, for benene blev helt reelt fejet væk under mig, og udsigten til et totalt forandret arbejdsliv stod ganske tydeligt. Notatet, vi blev præsenteret for, var allerede inden blevet drøftet i Hovedsamarbejdsudvalget på AAU.

Var jeg forberedt på udmeldingen? Nej, jeg havde virkelig ikke set den komme. Naiv? Nok havde Roskilde Universitet kort forinden indgået en samarbejdsaftale eller nok nærmere en overdragelsesforretning med KB - og AU overvejede at følge trop. Men jeg synes at Aalborg Universitetsbibliotek stod stærkt både indadtil og udadtil, og ikke sådan var i fare for at komme i spil.

Fælles udbud af nyt bibliotekssystem Men udmeldingen var anderledes. Vi var ikke blevet hørt. Forhandlingerne var hos os foregået på direktørniveau og jeg var tydeligt vred over, at vi ikke havde fået mulighed for at rådgive $\mathrm{i}$ forhold til de faglige forhold.

Springer jeg lige ud i "metaperspektiv", så vil jeg efterrationalisere og beskrive min oplevelse med følgende citat om ledelse af arketypen "Primadonna":

"Der er meget på spil for Primadonnaen. Oplever din Primadonna at blive forhindret $i$ at nå den højeste standard, foler han sig ikke blot demotiveret. Han føler et tab af eksistentiel mening, samtidig med at han føler, at han bliver tvunget til at sælge ud på den højere sags vegne."

(citat: lederweb.dk)

Sådan havde jeg det og jeg var reelt klar til at sige farvel til mit job, som jeg jo ellers var glad for og så lade "Danmarks Universitetsbibliotek", som det stod skrevet, lade være op til andre at indfri.

Jeg sidder her så stadig og kom nok til den accept, at skulle jeg forløse arketypens "kick", så måtte det blive gennem påvirkning af den proces, vi stod overfor. Acceptere og leve med de vilkår, der var uden for min indflydelse og så fylde på de steder, hvor der var rum til det.

Fra min stol var den konkrete udmøntning af samarbejdsaftalen, at vi hurtigt gik i gang med det fælles udbud af nyt bibliotekssystem. $\mathrm{Og}$ at det skete som ligeværdige parter.

\section{Profetisk notat - måske ved et tilfælde?}

Samarbejde kan have mange former, når det står skrevet i et notat, og det er svært at se graden og omfanget, før man kommer i gang. Det er jo slet ikke etableret.
Det opstår ikke af sig selv, det stiller krav til både en selv og til modparten. Hvem er man så at sige er på hold med? Er vi enige i fortolkningen af vilkår og rammer?

I forvejen var der sendt rystelser ind $\mathrm{i}$ Det Kgl. Bibliotek på grund af fusionen, så nok var de store og vi små, men KB skulle selv finde ind i nye samarbejdsrelationer og ledelsesstrukturer. På den måde var det måske nemmere at opbygge noget nyt og samarbejdende, hvor vi ikke kun blev set på som lillebror, men som en mere ligeværdig part. Notatet beskrev, at "skal et samarbejde indgås, vil det uden tvivl være en fordel at indgå det på nuværende tidspunkt, hvor der endnu er mulighed for at påvirke sektorens samarbejdsform og -betingelser".

Det var måske ikke skrevet med samme bagtanke, men jeg vil i dag påstå, at det var rigtigt set. Men, jeg tror også, at vi sammen har banet vejen til, at fremtidige samarbejder bliver nemmere at indgå.

\section{Hårdt arbejde fra alle sider}

Bevares, det kommer jo ikke ud af ingenting. Det har krævet hårdt arbejde fra alles sider. Man skal huske på, at "den lille" også skaber en masse uro og kaos hos modparten. Lige pludselig er der hensyn, der skal tages, som man tidligere havde den luksus at kunne være foruden. Kamelerne sluges på begge sider, når man samarbejder ligeværdigt. 


\section{I mit arbejde med bibliotekssystemer har vi i dag et velfungerende samarbejde mellem os, KB og senest CBS.}

Mit arbejdsliv blev selvfølgelig ændret væsentligt med det notat tilbage i 2017, men jeg er ikke blandt dem, der oplevede de allerstørste omvæltninger. I mit arbejde med bibliotekssystemer har vi i dag et velfungerende samarbejde mellem os, KB og senest CBS. Her i coronaens tid ser jeg endog mere til mine kolleger i KB end på AUB. En af de største gevinster: en masse fantastisk dygtige kolleger, som muliggør et helt nyt niveau af faglig sparring og hjælp.

Blev notatets visioner en så realitet? De konkrete, ja. Andre heldigvis nej. Her ville Primadonnaen også mene, at det ville have resulteret i et tab af eksistentiel mening og have været som at sælge ud på den højere sags vegne ...

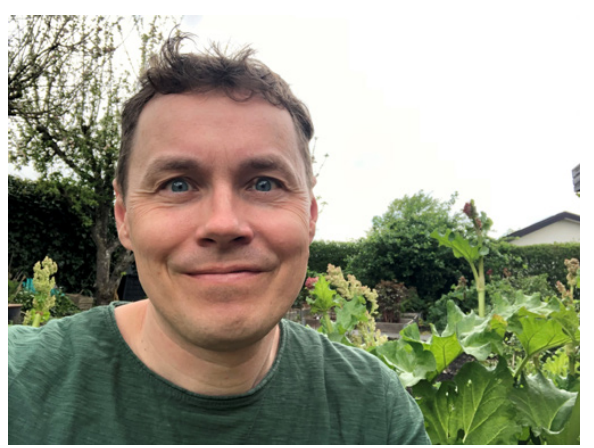

Kasper Lovschall er chefkonsulent ved AUB. Foto: privat 